\title{
PENGARUH BEBAN TEKAN TERHADAP KEMAMPUAN EKSTRAKSI MASSA CAIR SLURRY OLEH “ALAT PEMISAH FASES-URINE SAPI" YANG DIOPERASIKAN SECARA MANUAL
}

\author{
Nurpatria*, Yesung Allo Padang** \\ * Dosen Jurusan Teknik Mesin Universitas Mataram NTB, JI. Majapahit No 62 Mataram \\ ** Dosen Jurusan Teknik Mesin Universitas Mataram NTB, Jl. Majapahit No 62 Mataram \\ e-Mail : npatriazoeb@yahoo.com
}

\begin{abstract}
Cow manure can be used as a source of energy and as a solid or liquid fertilizer. An adult cow can produce fases (solid manure) to $23 \mathrm{~kg} /$ day and urine (liquid manure) $9 \mathrm{~kg} / \mathrm{day}$. Three or four cow is capable to fullfill the dayly needs of cooking fuel for one rural household. Cow manure slurry can also be convert as fertilizer, that is liquid fertilizer which is derived from urine and solid fertilizer originating from the solids. Solid and liquid from cow manure is usually mixed, therefore to make the liquid and solid fertilizer, the liquid and solid masses need to be separated first.

Recent separators of fases and urine are are electrical energy driven, so that those kind of device could not be used in the rural areas where the electric grid supply were not available. So that a model of a faces-urine separator of cow manure slurry is utilize which was constructed for manual pressing force. Moreover, through this research It have had created a manual fases-urine separator which only requires one operator. The separator consists of main parts including; lever press, chamber press, fases-urine separation mechanism, the mechanism of loading-unloading, and ajustment mechanism for pressing pressure.

This design is capable of performing the separation in a wide range of pressing force and it only requires one operator. Results Show That the model is capable to separate liquid from the slurry as much as $13.9 \%$ at a pressing force of $14 \mathrm{~kg}$ the which is applied for 18 seconds.
\end{abstract}

Keywords: Cow manure slurry, faces-urine separator, manual pressing force

\section{Pendahuluan}

Potensi kotoran sapi sebagai sumber energi dan pupuk sangat besar karena seekor sapi dewasa mampu menghasilkan fases (kotoran padat) hingga $23 \mathrm{~kg} /$ hari dan juga urine (kotoran cair) $9 \mathrm{~kg} /$ hari. Kotoran padat dan cair ini biasanya tercampur sehingga massa kotoran campuran sapi berumur muda sampai dewasa sekitar $15 \sim 30 \mathrm{~kg}$ setiap hari[2].

Bahan organik seperti kotoran sapi perlu dikomposkan sebelum dimanfaatkan sebagai pupuk tanaman karena dua hal; (a) bila tanah mengandung cukup udara dan air, penguraian bahan organik berlangsung cepat sehingga sangat menghambat pertumbuhan tanaman, dan (b) kotoran sapi tidak selalu tersedia pada saat diperlukan, sehingga pembuatan kompos merupakan cara penyimpanan sebelum digunakan sebagai pupuk. ${ }^{[1,2,3]}$

Untuk menyiapkan bahan baku pembuatan kompos seperti dimaksud diatas, maka tahap awal yang dilakukan pada slurry yang masih basah adalah pemisahan antara massa padat dan massa cair. Pemisahan massa padat dan cair slurry secara alamiah mengandalkan gabungan proses penguapan oleh panas matahari dan perpindahan massa dengan udara atmosfer. Cara ini membutuhkan waktu yang relatif lama yaitu $4 \sim 8$ Minggu tergantung cuaca.[1] Beberapa desain alat mekanis telah dibuat untuk keperluan ini[4]. Karena itu sangat diperlukan desain alat untuk memisahkan massa padat fases dan massa cair urine kotoran sapi, terutama jenis desain mekanis manual. 


\section{Metode Penelitian}

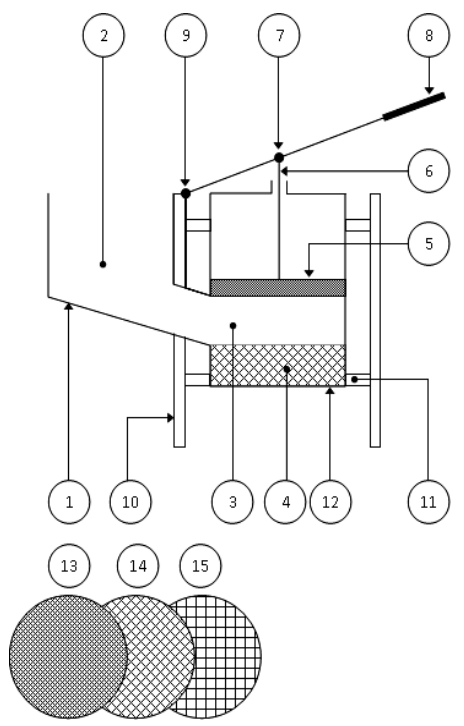

Gambar 1 Proses alat pemisah fases-urine sapi

Alat pemisah terdiri bagian utama Rangka, Mekanisme Press, Hopper Pemasukan Slurry, Mekanisme Pengeluaran Massa Padat, dan Mekanisme Pengunci. Alat yang dibuat adalah sebuah MODEL, skemanya seperti Gambar 3.1, mengingat keterbatasan dana penelitian. Walaupun ukurannya diperkecil, namun semua aspek teknis MODEL sama persis dengan PROTOTYPE sebenarnya. Perbedaan hanya pada kapasitas.

Hopper slurry (1) dilengkapi Salauran Masuk (2). Slurry masuk ke Celah Press (3), lalu menempati Cetakan Slurry (4). Slurry dipress Plat Penekan (5). Plat mendapat daya dari Batang Daya (6) yang digerakkan secara manual. Gaya press diatur dengan posisi Tumpuan Batang Daya (7) atau Tumpuan Tetap (9). Alat ini digerakkan dengan cara menarik Pengungkit Daya(8) secara manual.

Besarnya tekanan yang diberikan pada slurry dapat disesuaikan dengan menekan Plat Penekan hingga pada posisi vertikal tertentu.

Semua mekanisme yang telah disebutkan dipasang pada Rangka Utama (10) yang kokoh dengan Pemegang (11). Di bagian dasar alat disediakan lubang untuk mengeluarkan massa cair slurry. Lubang tersebut dilengkapi Bingkai Mesh (12) yang berfungsi ganda. Menahan massa padat tetap dalam cetakan namun massa cair dapat dikeluarkan. Massa cair ini ditampung pada alat terpisah yang tidak ditunjukkan dalam gambar. Bingkai Mesh tersebut terdiri dari Dua atau Tiga
Bingkai Mesh yang tersusun vertikal. Setiap bingkai tersebut diisi dengan mesh yang diinginkan, yaitu Mesh Halus (13), Mesh Sedang (14) dan Mesh Kasar (15). Mesh kasar didesain cukup kuat karena berfungsi menahan beban gaya press, sedangkan mesh halus berfungsi sebagai penyaring. Mesh sedang difungsikan untuk membantu mesh halus sekaligus memberikan pemerataan gaya sehingga membantu fungsi dari mesh kasar.

Pelaksanaan penelitian terdiri dari dua tahap; Tahap 1 proses desain dan pembuatan alat, dan Tahap 2 proses pengujian untuk mengetahui karakteristik kerja alat yang telah dibuat.

- Desain dan pembuatan alat. Alat yang akan dibuat didesain menurut pertimbangan ketersediaan biaya, kemampuan manufaktur lokal, pengembangan lebih lanjut, dan kemudahan perawatan.

- Pengujian Alat. Alat tersebut lalu diuji performancenya untuk variasi Gaya Tekan (F) terhadap Fraksi Pemisahan Massa Cair (X) dari massa total slurry.

\section{Hasil Penelitian}

\section{- Desain Alat.}

Gambar 1 menunjukkan lima tahapan kerja alat yang telah didesain. Lima tahap tersebut berulang menjadi siklus kerja.

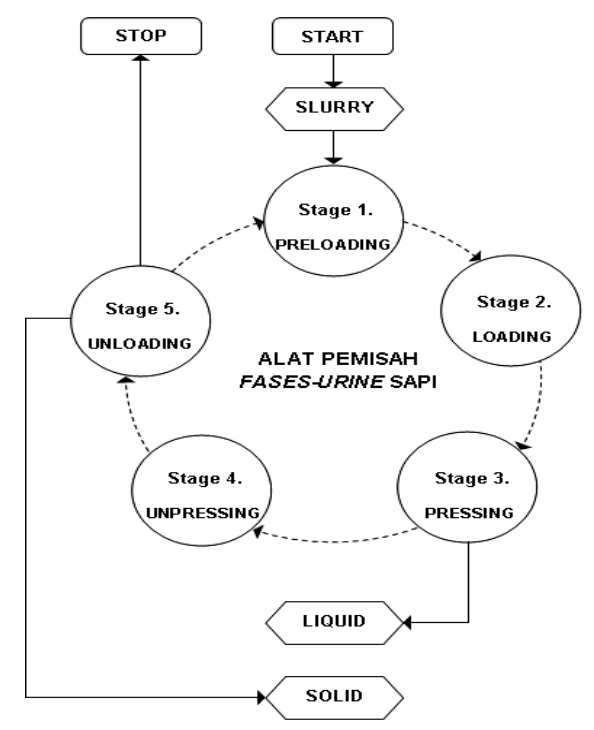

Gambar 3 Flowchart pelaksanaan penelitian 
- Performance

Alat yang dibuat diuji performancenya untuk memisahkan massa cair dari slurry. Pembebanan tersebut mensimulasikan besarnya kekuatan otot lengan operator yang diperlukan. Kekuatan otot maksimum rata-rata satu lengan lelaki dewasa asekitar $30 \mathrm{~kg}$, sehingga dalam penelitian ini dipakai kisaran $6 \sim 14 \mathrm{~kg}$. Dalam kisaran tersebut, diharapkan operator tidak cepat lelah dan dapat mengoperasikan alat hingga 4 jam. Mekanisme tuas tersebut dapat didesain sedemikian rupa agar kuat, ergonomis, dan memberikan efek magnifikasi gaya Faktor magnifikasi gaya adalah 2,7 dengan tekanan tekan maksimum pada pelat kempa hingga 11 $\mathrm{kPa}$.

Hasil pengujian pada Gambar 2 menunjukkan hubungan antara besarnya pembebanan beban tekan $(\mathrm{kg})$ dengan persentase fraksi Massa Cair dari materi Slurry. Waktu tekan semua data adalah sama yaitu, 6 detik. Ada dua hal penting yang bisa dilihat dari grafik tersebut.

Pertama, perubahan beban tekan (tuas), yang bisa diasosiasikan secara langsung dengan besarnya tekanan kempa, sangat berpengaruh terhadap kemampuan pemisahan cairan dari massa padat. Semakin besar tekanan kempa semakin besar persentase fraksi massa cair yang mampu diekstraksi. Performance pemisahan terbaik slurry yang diuji adalah pada pembebanan $8 \mathrm{~kg}$, yang menghasilkan kenaikan sekitar 5\% fraksi cair hanya dengan penambahan pembebanan $2 \mathrm{~kg}$ dari pembebanan awal $6 \mathrm{~kg}$. Penambahan pembebanan lanjutan sebesar $2 \mathrm{~kg}$ dari $8 \mathrm{~kg}$ hanya meningkatkan persentase tersebut sekitar $2 \%$. Demikian juga kenaikan pembebanan lain yang lebih besar menghasilkan penambahan dibawah $2 \%$. Keadaan tersebut dapat terjadi beban kempa yang semakin berat akan menyebabkan semakin intensnya pemadatan materi di akhir langkah kempa. Namun demikian trend umum yang terlihat pada press slurry tersebut adalah persentase pemisahan fraksi cair semakin tinggi dengan bertambahnya beban tuas.

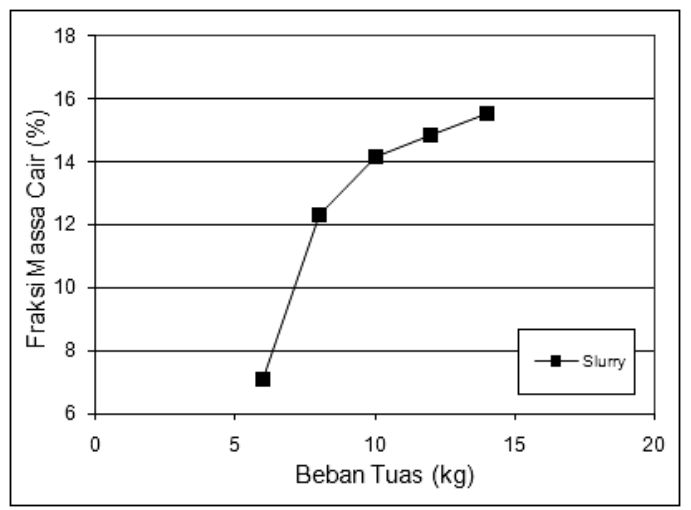

Hal kedua adalah trend besarnya persentasempermisetganuh caikranudsine pada setiap kenaikan pembebanan yang konstan dimana semakin besar beban, penambahan persentase fraksi massa cair selalu lebih kecil. Atau, perubahan beban tekan terhadap perubahan fraksi massa cair tidak linier. Perubahan karakteristik porositas materi sangat mungkin menjadi penyebab hal itu. Pemadatan materi menyebabkan massa cair semakin sulit diekstrak.

Tabel 1. Karakteristik pemisahan

\begin{tabular}{llrrrrr} 
Waktu tekan tuas & $(\mathrm{s})$ & 6 & 6 & 6 & 6 & 6 \\
\hline Beban tuas & $(\mathrm{kg})$ & 6 & 8 & 10 & 12 & 14 \\
\hline Massa Awal Materi & $(\mathrm{gr})$ & 2003 & 2003 & 2003 & 2003 & 2003 \\
\hline Massa Cairan & $(\mathrm{gr})$ & 142 & 251 & 283 & 297 & 311 \\
\hline Massa Akhir Materi & $(\mathrm{gr})$ & 1861 & 1752 & 1720 & 1706 & 1692 \\
\hline
\end{tabular}

Tabel 1 menunjukkan data absolut pengukuran massa awal slurry, massa cairan hasil ekstraksi yang ditampung selama pengujian, dan massa akhir materi padatan. Pengujian dilakukan pada waktu tekan kontan 6 detik. Massa awal materi slurry, yaitu campuran (yang dibuat) homogen antara massa padat dan massa cair, adalah 2003 gr yang diukur langsung. 


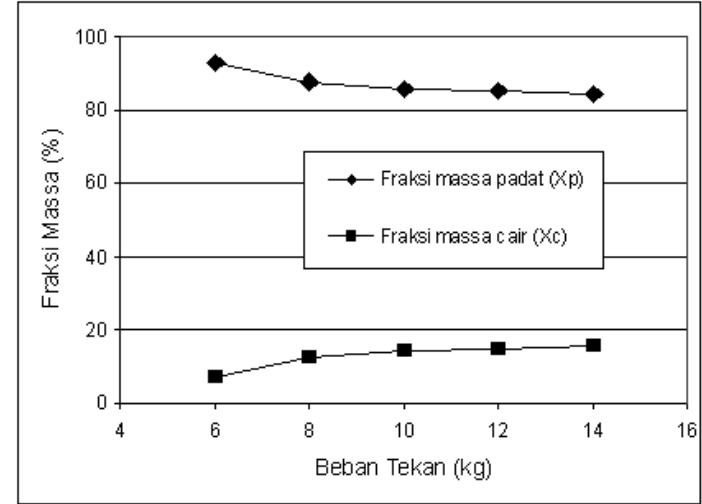

Dalam Gambar 3 ditunjukkan perubahan nilai fraksi massa cair $(X c)$ dan massa padat $(X p)$ slurry pada berbagai beban tekan.

Massa cair yang keluar dari alat mengurangi berat dan volume massa yang tersisa dalam ruang tekan. Kelandaian garis trend perubahan menunjukkan bahwa pada akhir langkah kompresi, performance alat menurun.

\section{- Aspek Teknis}

Alat yang telah dibuat memiliki beberapa keunggulan dan juga beberapa keterbatasan, terutama menyangkut masalah desain serta pemilihan parameter operasinya. Selain itu, alat ini juga dapat dijadikan model untuk pengembangan alat serupa untuk meningkatkan performance, cakupan bahan, kapasitas, maupun kualitas produk yang dihasilkan.

Alat ini memiliki keunggulan utama yaitu bertenaga manual dan hanya memerlukan satu operator. Desain yang dibuat memungkinkan operator melakukan lima tahap siklus pada Gambar 1 hanya dengan kedua tangan saja tanpa bantuan kaki. Semua proses dapat dilakukan secara kontinu tanpa perlu bolak balik meninggalkan tuas penekan. Materi slurry dalam hopper untuk banyak siklus kempa dan hopper dapat dibuat lebih besar jika diinginkan lebih lama. Karena bertenaga manual, alat ini sangat cocok dipakai di pedesaan yang jauh dari sumber listrik. Alat ini dapat dipakai juga untuk membuat briket biomassa dari kotoran sapi, yaitu dengan menambahkan satu komponen pada plat kempa. Tekanan kempa juga dapat dengan mudah disesuaikan dengan jalan mengganti jenis pegas.

Selain keunggulan diatas, desain alat ini juga masih mempunyai beberapa keterbatasan. Persentase cairan yang bisa dikeluarkan masih terbatas dan ini disebabkan pembatasan pada besarnya tekanan kempa yang mampu dihasilkan otot manusia. Selain itu, alat ini juga masih perlu disempurnakan terutama pada bagian kontak luncur yang rawan kemacetan.

Alat ini dapat dikembangkan untuk mengatasi masalah tekanan kempa yang rendah. Solusi desain yang bisa dilakukan adalah dengan membuat sistem hidrolik yang berkarakteristik tidak memerlukan pasokan daya luar dan dapat dibuat dengan teknologi manufaktur konvensional yang murah.

\section{Kesimpulan}

- Telah bisa dibuat sebuah alat pemisah fases dan urine dari slurry kotoran sapi.

- Alat yang dibuat mampu memisahkan cairan dari slurry sebanyak maksimum $15,5 \%$ pada tekanan kempa $11 \mathrm{kPa}$ yang diaplikasikan selama 6 detik.

- Kemampuan alat akan bervariasi tergantung karakteristik slurry yang diproses, hal ini ditandai dengan berubahnya performance alat terhadap perubahan gaya tekan.

\section{Daftar Pustaka}

[1] Prihandini, P.W., Purwanto, T., 2007, "Kompos Berbahan Kotoran Sapi", ISBN: 978-979-8308-75-8, Pusat Penelitian dan Pengembangan Peternakan Departemen Pertanian, Pasuruan JATIM

[2] Ridawan, 2006, "Kotoran Ternak Sebagai Pupuk dan Sumber Energi", Publikasi Independen Online Harian Singgalang Edisi 1 Pebruari 2006, www.disnak.jabarprov.go.id (Akses: 24 April 2010)

[3] Santi, I.N., 2004, "Pemanfaatan Kotoran Ternak Skala Rumah Tangga Sebagai Sumber Energi Alternatif Biogas", http://125.163.204.22/, (Akses:.24 April 2010)

[4] Sutimbul, C., 2006, "Analisis Kerja Mesin Hidrolik Pencetak Paving Dengan Sistem Hand Control Hydraulic", Perpustakaan Digital Universitas Negeri Semarang, Semarang 